\title{
Re-presenting the French Revolution: the impact of Carlyle's work on British society and its self- representation
}

La représentation de la Révolution française : l'impact de l'œuvre de Carlyle sur la société britannique et la façon dont elle se représentait

\section{Catherine Heyrendt-Sherman}

\section{CpenEdition \\ Journals}

\section{Electronic version}

URL: http://journals.openedition.org/rfcb/6118

ISSN: 2429-4373

Publisher

CRECIB - Centre de recherche et d'études en civilisation britannique

\section{Printed version}

Date of publication: 1 June 2010

ISSN: 0248-9015

\section{Electronic reference}

Catherine Heyrendt-Sherman, "Re-presenting the French Revolution: the impact of Carlyle's work on British society and its self-representation", Revue Française de Civilisation Britannique [Online], XV-4 | 2010, Online since 01 June 2010, connection on 07 January 2021. URL: http:// journals.openedition.org/rfcb/6118

This text was automatically generated on 7 January 2021.

Revue française de civilisation britannique est mis à disposition selon les termes de la licence Creative Commons Attribution - Pas d'Utilisation Commerciale - Pas de Modification 4.0 International. 


\title{
Re-presenting the French Revolution: the impact of Carlyle's work on British society and its self- representation
}

\author{
La représentation de la Révolution française : l'impact de l'œuvre de Carlyle sur \\ la société britannique et la façon dont elle se représentait
}

Catherine Heyrendt-Sherman

1 The French Revolution and its representation in Britain are key topics when it comes to the distinction between 'the literature of knowledge' and 'the literature of power' established by De Quincey in 1848. As historian Hedva Ben-Israel puts it, in Britain, 'the greatest effects of the Revolution have been wrought through the power of words on paper.'1 Attempts to write about the French Revolution, especially before the emergence of the contemporary source-critical, fact-oriented historian, ${ }^{2}$ almost unavoidably participated in the making of history, blurring the distinction between knowledge and power. Thus, the concepts created through writing on the Revolution 'are both a product of and an influence on the society of which they form a part'. ${ }^{3}$

2 In the 1790s, British thinkers like Burke, Paine or Godwin tended to write the story of the Revolution even before it was completed, leaving behind texts which, in the best cases, transcended the period to become classics in political theory. It was all the more important to control the topic since there was a developing readership eager to know about political matters. ${ }^{4}$ As years went by, more and more seemed at stake for British society. Besides the enduring comparison with Britain's own Glorious Revolution, there was a need to address and adjust to the considerable economic and social changes resulting from industrialisation. Dror Wharman has argued that the French Revolution helped shape British society around the middle classes, their absence in France being blamed for the horrors of the Terror. ${ }^{5}$ More generally, British national identity had to 
be redefined, as people's awareness of the transformations around them became more acute, often in conjunction with the debate on machinery and mechanisation ${ }^{6}$.

By the 1820s, the political debate on the Revolution had been replaced by ideological considerations connected with the problems of the day and the self-representation of British society. In this respect, Thomas Carlyle's The French Revolution, a History (1837) came at a crucial juncture. Carlyle was still part of what Levine defines as 'an older tradition of essayists and reviewers', as opposed to later professionalised historians. Although Carlyle arguably 'redeemed the study of history at a moment when it was being threatened by a host of convergent forces', his own brand of history defies $21^{\text {st }}$ century definitions, aiming to resurrect the events through a highly subjective prose which has been considered, not without reason, akin to epic poetry. ${ }^{8}$

Carlyle was possibly one of the last writers to perpetuate the tradition of history as written by men of letters; and, at the same time, he was one of the very first to write on the Revolution with enough chronological distance and perspective to rise above the previous political debate, fraught as it was with fear and, often, uncompromising reprobation. Carlyle's unique position meant that he was wielding perhaps not so much a literature of knowledge as a literature of power, unlike his counterparts William Smyth, John Croker or Lord Acton. Ben-Israel points out that Smyth 'wrote lectures frankly intended as guides to reading', while Croker's articles 'are in the form of book reviews' and Acton 'betrays a predominating interest in the historiography'. 'On the contrary, Carlyle aimed neither for an academic evaluation of his predecessors, nor for a critical approach to the different sources available, though he did review some of his primary material in the course of his research. ${ }^{10}$ Carlyle gave up trying to use the British museum's collection of pamphlets, was moderately enthusiastic about French historians like Thiers and, to an extent, favoured biographies and individual impressions. ${ }^{11}$

5 Thus, Carlyle was less interested in his sources themselves than in re-creating the events and the atmosphere - ideological and emotional - that surrounded them, for the benefit of contemporary Britons. His lack of preoccupation with the academic details favoured by the likes of Smyth even led him to be allusive about events which he considered known to his reader, and on which he was only interested in casting a new light. A disgruntled reviewer of the Literary Gazette can be forgiven for considering that, in Carlyle's book, 'There is nothing like a history of the events which took place; but, instead, there is a series of rhapsodical snatches, which may remind readers acquainted with the facts, from previous histories and memoirs, what it is that the author is really writing about. ${ }^{\prime 2}$

6 The function of Carlyle's text was primarily to move, making it part of 'the literature of power'. This does not mean that the teaching objectives were absent, or that The French Revolution was not meant to be literature of knowledge as well; but, in order to convey his groundbreaking points - notably on the inevitability of the events and the need to pity rather than blame the tempest-tossed revolutionaries - Carlyle needed to appeal to British emotions and collective consciousness.

7 The vision that Carlyle proposed was innovative in two related ways. Firstly, he made the revolution seem, if not less shockingly violent, at least more inevitable and possibly justifiable - a major departure from Burke's views, which had been very popular (especially since the Terror). Secondly, the proposition that the Revolution did not consist of gratuitous crimes perpetrated by isolated sanguinary brutes, but was rather a response to a more widespread European situation, made a comparison with Britain 
appear less objectionable. Now that Revolutionary France seemed less of a threat (either through war with Britain or through ideological subversiveness susceptible to agitate the lower echelons of British society), it became possible to envisage a parallel with Britain and enrich the reflexion on the national situation in the 1830s. The rest of this article will tackle these two innovations in representing the Revolution, and the possible impact on British self-representation at the time.

\section{Living up to a traditionally violent imagery?}

When Carlyle's book came out in 1837, the prevailing image of the Revolution was negative and even terrifying. Early on, Paine's favourable views had been largely superseded by Burke's condemnation. Burke denounced, among other unflattering characteristics, the 'ferocious dissoluteness' and the 'insolent irreligion' of the revolutionaries. ${ }^{13}$ Only 'idleness, luxury, dissipation, and insubordination' ${ }^{14}$ had led to the terrible events which Burke described with emphatic repulsion. ${ }^{15}$ Burke's contention is that the revolution was 'unnatural' and not 'inevitable'16 - two assertions which Carlyle sets out to contradict, as will be seen here. At the time when Carlyle wrote, almost half a century after Burke, the prevailing imagery remained deliberately brutal, as evidenced by the opening of Madame Tussaud's Chamber of Horrors in 1802. In The Culture of History, Billie Melman points out that the exhibition, seen by some as an institution, was set up sensationally, much in the manner of public executions. It was, however, deemed respectable, and suitable for women and children; ${ }^{17}$ as a result, its hold on collective imagination was powerful. British representations of the revolutionary French people remained emphatic and even graphic regarding the violence. Closer yet in time to Carlyle's endeavour, were the historical narratives of Walter Scott. In his Life of Napoleon, Scott tapped into the popular reservoir of gruesome revolutionary images, depicting the hanging of a baker whose severed head is then presented to his wife for a kiss. ${ }^{18}$

Carlyle could not escape certain topoi of revolutionary history, not only because he wanted to resurrect and get to the truth of an essentially violent period, but also because they were deeply anchored in public imagination and expected of him. Besides, he had been exposed to some of the same imagery as a large part of the British public had been, and his own subjective and lively way of writing history naturally led him to vivid renderings. Thus, he strikingly represents scenes of massacres - from collective drownings (where the cruelty of men is deemed worse than that of the fiercest and most desperate animals ${ }^{19}$ ) to public beheadings where the victims, singing the national anthem, form a tragically diminishing chorus rhythmically losing one participant per minute..$^{20}$ So while popularity never ranked high among Carlyle's ambitions, his natural style and inclination, applied to a loaded (and perhaps exquisitely frightening, as we will see) topic, triggered enthusiastic approval, and may account in part for the resounding success of his book, which finally gave him recognition and financial stability when he was 42 . 


\section{'Every man holds a madman confined': re-humanising the mob}

But for all the weight that Carlyle gained by revisiting the paradoxically appealing violence of the Revolution, he still managed to depart from traditional interpretations by suggesting justifications for barbaric actions, and by making the revolutionaries come across as more humane. Thus, the 'mob' he describes, labelled as 'Rascality', 'populace', 'rabble' or even 'canaille', ${ }^{21}$ turns out quite early on to be a sort of Trojan horse. Carlyle denounces the tendency to make them appear as one entity, when they are in fact individuals, struggling and to be pitied:

With the working people, again, it is not so well. Unlucky! For there are from twenty to twenty-five millions of them. Whom, however, we lump together into a kind of dim compendious unity, monstrous but dim, far off, as the canaille; or, more humanely, as 'the masses'. Masses indeed: and yet, singular to say, with an effort of the imagination (...) the masses consist all of units. Every unit of whom has his own heart and sorrows; stands covered there with his own skin, and if you prick him, he will bleed. ${ }^{22}$

In order to fight this abusive and dehumanising amalgamation, Carlyle resorts to the expression 'the Twenty-five Millions' more frequently than necessary. ${ }^{23}$ Other groups such as the assembly are also occasionally referred to by stating their numbers. Moreover, building on his long-established skills as a biographer, Carlyle takes care to extract individual figures, real or imaginary, named or anonymous, such as 'the beggar with his crust moistened in tears' ${ }^{24} \mathrm{He}$ is careful with individual portraits, sometimes achieving new insights: he depicts Charlotte Corday as brave and heroic, contradicting the initial condemnation of Marat's murder by British historians..$^{25}$

Having shown the humanity and the individuality of his subjects, Carlyle tackles the often violent and controversial emotions which animate them. Again, he starts with characteristics extant in previous representations, building up variations on the themes of 'wildness', 'evil' and 'madness'. ${ }^{26}$ However, aside from the fact that these words are not always as negative as might be expected, ${ }^{27}$ Carlyle quickly prevents his British reader from feeling complacent, by making it clear that these attributes are not specific to the French. He does express the view that the French invented the Art of Insurrection, and that their national temper makes them more prone to react to problems common to all European countries ${ }^{28}$. But he also defines the Revolution as 'the Madness that dwells in the hearts of men' in general, having insisted that 'every man holds a madman confined ${ }^{29}$, irrespective of nationality.

Although Carlyle does hint, like Burke, that scepticism may be blamed for the resurgence of such evil (I, 16), he thinks there is something unavoidably cyclical to crises, including spiritual ones: 'the "daemonic element" that lurks in all human things, may doubtless, some once in the thousand years, - get vent!' (I, 41). What is more, the cycle may be impossible to break, as is suggested by the narrator who claims: 'to abolish the old France, and make a new one (...) this, by the law of nature, has become inevitable' (I, 228). The word 'inevitable' occurs thirty times in The French Revolution, perhaps on purpose to contradict Burke's description of events 'not inevitable'. More importantly, indolence, Carlyle claims, is to be blamed for these spasms - which is perhaps another hint at his countrymen and their potential self-satisfaction at having avoided a revolution (other 
than the relatively smooth Glorious Revolution). Carlyle may be issuing a warning against letting social crises deteriorate for too long.

\section{'Horrible, in Lands that had known equal justice! Not so unnatural in Lands that had never known it!'}

Having made revolutionaries look less like a mob, and more like a set of individuals likely to resemble at least some sections of British society, Carlyle proceeds to give them direct justification. Thus 'Rascality' is echoed by 'Drudgery', 'Hunger' or 'scarcity', often starting with a capital letter for emphasis. Misery, hunger, exploitation and fatigue are ubiquitous, especially at the beginning of the book. Within the space of half a dozen lines, the reader may be confronted with 'starvation', 'sallow faces', 'wretchedness and raggedness', 'Hunger and Darkness, through long years!' (I, 235). The narrator, through an interplay of pronouns, sides with the reader and the revolutionaries in turns, and possibly both at times. He often calls for pity for those 'rising against tyrants' (II, 318-319), even highlighting the perils they incur (II, 102). When intendant François Berthier is murdered, and his head and heart displayed on pikes, the narrator comments: 'Horrible, in Lands that had known equal justice! Not so unnatural in Lands that had never known it! ${ }^{30}$ Thus, mitigating circumstances are often found. ${ }^{31}$

Carlyle also powerfully points out the relativity of existing condemnations. Accounts of the revolution were delivered by the more literate part of the population, that is to say those who were better off socially and thus more likely to be targeted by the Terror. $\mathrm{He}$ insists that the greater part of the population actually saw improvements in their living conditions:

History [...] confesses mournfully that there is no period to be met with, in which the general Twenty-five Millions of France suffered less than in this period which they name Reign of Terror! But it was not the Dumb Millions that suffered here; it was the Speaking Thousands, and Hundreds, and Units; who shrieked and published, and made the world ring with their wail, as they could and should: that is the grand peculiarity. ${ }^{32}$

So while the terrible events are not excused, it is argued that they brought the greatest good to the greatest number - a potentially convincing argument at a time when utilitarian views were widespread (although Carlyle did not share them).

Yet it is maybe not the more explicit justifications which convinced the British reader to take a second look at the Revolution in correlation with Britain and British problems. Perhaps because he bore in mind the charges (notably laid by Burke) of 'unnaturalness' of the Revolution, Carlyle sets out to give series of animal and natural images that alleviate the responsibility of the French people. Animal metaphors are used throughout the text to describe revolutionaries. Compared with generic beasts (e. g. 'a dumb tortured animal', I, 16), the people mostly appear, initially, as farmyard animals. They are a 'flock not tended (...) only regularly shorn' (I, 15). Or they are chickens, whom their farmer consults to find out what sauce he should dress them with to be eaten (I, 78). When the king turns up at the assembly on a day when he had strategically announced a royal hunt, he is described as hunting 'two-legged unfeathered game' (I, 95). But gradually, after Finance minister Joseph-François Foulon de Doué declares that 'people may eat grass' (I, 117), the people turn, understandably, into more rebellious animals: 
behold, this monstrous twenty-million Class, hitherto the dumb sheep which these others had to agree about the manner of shearing (...) has ceased or is ceasing to be dumb; it speaks through pamphlets, or at least brays and growls behind them, in unison,- increasing wonderfully their volume of sound. ${ }^{33}$ like fire, they can hardly be controlled. While Carlyle condemns the people's inability to use their internal fire strategically, he points out later how vain it would be to attempt to predict or control an insurrection which is a 'volcanic lava-flood'. ${ }^{35}$ Summary executions are likened twice to a 'thunder-cloud' (FR I, 218), an image perhaps reminiscent of Blake's engravings. For a more detailed study of the fire imagery in Carlyle's works, see Jacques Cabau's work. ${ }^{36}$ Predictably, those thundery weather conditions lead to a downpour, and water appears as a key element. and 'flood'. They are used mostly to describe crowds, such as 'the whole loose fluent population of Paris [...] inundating these outer courts, like a loud destructive deluge' (I, 88). 
Later, 'deluges of frantic Sansculottism' pour into the Tuileries, seeking revenge (II, 114). The word 'sea' (or 'seas') appears 88 times, in a context which has essentially nothing to do with the actual sea: 'seas of people', 'sea of persons', (I, 174-175), 'roaring sea of human heads', (FR I, 292), 'insurrectionary sea', (FR 110-111), 'ocean-tide of pikes and fusils. ${ }^{37}$

Like the animal metaphors, the elemental ones are ambiguous, but natural: they detract from the notion that the people are responsible for the violence of the revolution, since nobody can control a storm. ${ }^{38}$ We will see that the inherent sense of threat - conveyed by water especially - and the notion of shipwreck, had a strong impact on the British public and its view of itself. The republic appears as a precarious boat, and the relative absence of the Earth during the course of the book leads to a relieved conclusion towards the end: 'O Reader!- Courage, I see land!' (FR II, 418), as if the reader was undergoing a similar experience of being tossed about on the sea.

\section{Re-presenting the Revolution: a newfound proximity}

As soon as the French cease to come across as outlandish barbarians whose actions are unredeemable or even unaccountable, identifying with them - or at least comparing oneself to them - becomes easier, and problems arise. The French upheaval can no longer be blamed on the fiery and unreasonable French temper. As a result, Britain, which might have been thinking of herself as made of different stuff, might have to start worrying. If the French had been inevitably and not unnaturally - as Carlyle suggests - drawn towards a revolution for which they could not be held responsible, why should Britain not end up in a similar predicament? As if to encourage this line of thought, Carlyle introduces discreet references to 1830s Britain, sowing seeds that will develop into his later works Chartism and Past and Present. These hints may have been part of the conscious or unconscious attraction of his book, creating a certain thrill of danger.

The British reader, or rather spectator, as will be seen, is in a way manipulated, and thrown in the midst of a shipwreck. He derives pleasure in knowing that his own position is safe - yet not so safe as to preclude excitement. The safety is achieved by the distance, in time, especially. The sentiment of danger stems from the parallel references to Britain, and from the highly vivid narrative that only Carlyle, as one of the last atypical historians-cum-men-of-letters, can provide. Hans Blumenberg's theory in Shiffbruch mit Zuschauer (Shipwreck with Spectator) ${ }^{39}$, is especially enlightening in considering how the re-presentation of the Revolution may have influenced the selfrepresentation of British society.

Indeed, in conjunction with the water imagery discussed earlier, the notion of shipwreck is introduced - out of 24 references to 'wreck' and derived words like 'wreckage' or 'shipwreck', only two have to do with real rather than metaphorical incidents. The French Revolution is made of successive shipwrecks, like those of the legislative assembly, of Mirabeau or of the Girondin movement. The central shipwreck, though, is that of the French State, and while disaster often seems imminent, it is ultimately avoided. ${ }^{40}$ The happy ending turns the French republic into a myth and the Revolution into a miracle:

The Ship is over the bar, then; free she bounds shoreward,-amid shouting and vivats! (...) The miraculous Convention Ship has got to land;-and is there, shall we 
figuratively say, changed, as Epic Ships are wont, into a kind of Sea Nymph, never to sail more; to roam the waste Azure, a Miracle in History! (II, 450) pleasure in escaping danger. Blumenberg comments on the enjoyment of knowing that one's position is not at risk. He insists that the pleasure does not reside in the sublime characteristics of the object under contemplation, but in the viewer's selfconsciousness in the face of what he is watching. ${ }^{45}$ In that respect, Carlyle's own role is twofold: resurrecting the events to rekindle the sense of danger, and making his potential warning to British society acceptable, by stressing the feeling of security. Thus the narrator of The French Revolution exclaims 'Thou, $O$ reader, at such safe distance' (II, 75).

This precarious yet gratifying sense of security, skilfully balanced, could explain, on the one hand, the resounding success of Carlyle's book on its publication and, on the other hand, the decline of its popularity as the events it described receded in time and as British society felt less threatened by the social and political upheaval of the 1820s-1830s. Carlyle did not resort to his system of metaphors with a view to selling more books or appealing to the collective psyche - metaphors are, in their own right, a way to mediate the history of concepts, fulfilling people's need to approach the world as a book, a didactic play orchestrated by providence. ${ }^{46}$ The conceptual frame is thus subjective, more because the nature of the events and their problematic representation make it unavoidable than because of any will to manipulate the reader. The result, in any case, was that Carlyle's attempt to deliver the past as a 'letter of instruction' ${ }^{47}$ to posterity succeeded. 


\section{A warning to Britain}

The reader's attention is deliberately oriented towards his own country, the aim being perhaps to prod him and to induce self-critical reflexion - perhaps somehow to move and teach at the same time (as is the case for the 'literature of power' and 'literature of knowledge'), though the narrator never dictates what one should think, aiming only for awareness and questioning.

Britain is represented in The French Revolution both as France's neighbour at the time of the events, and as a troubled society at the time of publication. Connections between French and British history are highlighted throughout: anglophile French immigrants, British 'missionaries' in France acting in spite of the disapproval of Burke and the Tories, French animosity against Pitt, Paine's adventures and narrow escape from the Guillotine. ${ }^{48}$ Carlyle even sees a parallel between the French insurgents and the Scottish signatories of the 1638 Covenant. ${ }^{49}$ Thus the partition between the two countries' history is undeniably porous.

But the most striking parallels are those with 1830s Britain. Carlyle wrote his book just as the 1833 Factory Act and the 1834 Poor Law were passed. The Poor Law, especially, planned for Workhouses - institutions that were almost prisons, meant to offer worse conditions than those experienced by the employed poor, according to Chadwick's principle of less eligibility. It is not too much of a stretch to the Bastille, and Carlyle makes this leap in Past and Present (1843), mentioning 'the workhouse Bastille' in the second paragraph.

In Victorian minds, the poor were often considered to be deliberately idle, and thus responsible for their destitute situation, the question of unchosen unemployment being overlooked. It is perhaps no coincidence that Carlyle takes the trouble to relate a speech by Marat, in which the population is told: 'your indigence is not the fruit of vices nor of idleness.' (I, 413) Elsewhere, the narrator is indignant 'to see so many millions of hands, that would be industrious, all idle and starving', due to the bad management of the land by the Lords, concluding: 'such an arrangement must end' (I, 239). This denunciation tallies with Carlyle's other condemnations of the idle aristocracy, for instance in Past and Present. Carlyle's appreciation of the new tax system set up under the French republic (consisting in high taxation of 'superfluous revenue') makes us wonder if he would advocate the same for Britain - he comments: 'Unexampled enough; it has grown to be no country for the Rich, this; but a country for the Poor!' (II, 268). Further, perhaps as a warning to his countrymen, he states that injustice is doomed to failure (II, 402).

In a similar denunciation of beliefs and practices common in his day and age, Carlyle tackles the downside of economic laissez-faire: 'Who are they that [...] when we ask for bread, and a Maximum fixed-price, treat us with lectures on Free-trade in grains?' ${ }^{50}$ When the narrator asks 'Can the human stomach satisfy itself with lectures on Free-trade [...] ${ }^{51}$, he might as well be speaking about Britain, and seems favourable to social intervention. The question of the price of grain was also a sore subject in Britain, as it was maintained artificially high by the Corn Laws (repealed in 1846). All of these questions were present in the minds of the public, especially those of the middle classes, who had emerged from the industrial revolution and were developing a set of humanitarian values (leading, for instance, to the regulation of work, at least for women and children, and to the abolition of slavery in 1834). 


\section{Conclusion}

37 Carlyle's The French Revolution is a contribution which comes at a pivotal point in time. Almost fifty years after the events, the fierce fight waged in the 'literature of power' of the likes of Burke and Paine had died down. Yet, British 'literature of knowledge', with strict historiographic rules and an impartial assessment of sources had not yet tackled the Revolution. What Carlyle does, in a way, is to use subjective and literary style and techniques (akin to that of the literature of power) in order to provide a shift in knowledge, or at least in perception. He tries to open new perspectives and angles for the reader, changing forever Victorian perceptions of the French Revolution and its actors.

38 Natural metaphors suggest inevitability, and a limited responsibility. Carlyle, at least, asks his contemporaries to suspend judgement - a considerably novel approach to the Revolution at the time: 'How it was and went, what part might be premeditated, what was improvised and accidental, man will never know, till the great Day of Judgment make it known' (II, 147). Empathy prevails, as well as the desire to understand rather than apportion blame. The reader is drawn into the narrative, and made to feel simultaneously concerned and at a safe distance.

Gradually, however, doubts entre the reader's mind: Britain, which is experiencing social unrest, may not be exempt from revolutionary velleities, hence the need to learn lessons from history. The image of France as the powerless instrument of destiny, subjected to a fascinating yet ineluctable shipwreck, served a double, albeit temporary, purpose. It first shook and uprooted existing beliefs and images of the Revolution, making it possible for them to be replaced by others. It also averted complacency about Britain's smoother course, so that she might better turn her attention to the social issues of the $19^{\text {th }}$ century. This may explain the diminishing popularity of The French Revolution once it had served this purpose. Yet the book remains among Carlyle's most powerful texts in social history, alongside Past and Present.

\section{NOTES}

1. Hedva BEN-ISRAEL, English Historians on the French Revolution, Cambridge: CUP, 1968, xii, 312pp., p. ix.

2. Cf. Philippa LEVINE. The Amateur and the Professional. Antiquarians, Historians and Archeologists in Victorian England, 1838-1886, Cambridge: CUP, 1986, ix, 210 pp. Levine establishes a distinction between full-fledged historians who were part of a 'wider historical community', and others who were rather 'polemicists or popularisers' or 'found their associates and friends rather in literary and political circles of a more general kind' (pp. 3, 24).

3. Hedva BEN-ISRAEL, op. cit., p. x.

4. Ibid., pp. 3-5.

5. Dror WHARMAN, Imagining the Middle Class. The Political Representation of Class in Britain, $c$. 1780-1840, Cambridge: CUP, 1995, xvi, 428pp. According to Wahrman, the French events 'were the 
catalysts for the reconfiguration of the British political debate of the 1790s', leading to a new significance of the term 'middle-class' (21). The existence of that class was critical: its disappearance in revolutionary France is sometimes considered as a major cause for the Terror.

6. Cf. id., pp. 228-229, and also Maxine BERG, The Age of Manufactures 1700-1820, Second edition. London: Routledge, 1994, xiv, 337 pp.

7. Cf. Philippa LEVINE, op. cit., p. 3. Macaulay is associated with Carlyle, and both are, for the most part, dismissed from the study, since they do not meet the definitions 'historical communities would have laid down for themselves.' (p. 3).

8. In an anonymous article which greatly contributed to the success of The French Revolution, John Stuart Mill wrote that the book was 'not so much a history, as an epic poem.' (London and Westminster Review, July 1837, republished in The Critical Response to Thomas Carlyle's Major Works, edited by D.J. TRELA and Rodger L. TARR, London: Greenwood Press, 1997, 205 pp., pp. 52-68, p. 52 for the quotation). Carlyle would not have disavowed the comment, since he claimed to consider the Revolution as 'the grand poem of our times' in a letter to J.S. Mill (The Collected Letters of Thomas and Jane Welsh Carlyle, edited by Ian CAMPBELL, Aileen CHRISTIANSON, David R. SORENSEN et al., Durham (North Carolina): Duke University Press, 1970- , VI, 446). He also wrote to Emerson that 'the only Poetry is History' (VII, 266).

9. Hedva BEN-ISRAEL, op. cit., p. 275. She considers that 'Carlyle alone had only a secondary interest in the books he used'. This assertion can be qualified by the fact that Carlyle, like Croker, wrote at least one book review on material pertaining to the Revolution - see the following footnote.

10. One of the books Carlyle found the most useful, Histoire Parlementaire de la Révolution française by Buchez and Roux, is still of value to historians today. Cf Thomas CARLYLE, 'Parliamentary History of the French Revolution', London and Westminster Review, April 1837 (republished in Thomas CARLYLE, Critical and Miscellaneous Essays: Collected and Republished (London: Chapman \& Hall, 1888, 7 vol., vol. 7, 244 pp., pp. 1-20).

11. For more on Carlyle's sources, see Carlyle's letters (Collected Letters, op. cit., VII, 289 for the British library's resources) and David Sorensen's work (for instance his article “'Natural Supernaturalism': Carlyle's Redemption of the Past in The French Revolution", in LISA, Vol. VII $\mathrm{n}^{\circ} 3$, 2009, Festschrift honouring René Gallet, http://lisa.revues.org/index132.html). Sorensen's introduction to the future Strouse edition of The French Revolution should provide a more comprehensive and definitive outlook. See also chapter 3 of my PhD thesis Carlyle et la France (Université Paris III - Sorbonne Nouvelle, directed by Franck Lessay, defended in October 2006).

12. Anon., Literary Gazette, and Journal of the Belles Lettres, $n^{\circ} 1062$ (27 mai 1837), republished in The Critical Response to Thomas Carlyle's Major Works, edited by D.J. TRELA and Rodger L. TARR, London: Greenwood Press, 1997, 205 pp., pp. 49-50.

13. Edmund BURKE, Reflections on the Revolution in France (1790), ed J.G.A. POCOCK, Indianapolis \& Cambridge: Hackett Publishing, 1987, lvii, 237 pp., p. 33.

14. Ibid., p. 188.

15. See for example ibid., p. 63: 'Their heads were stuck upon spears and led the procession, whilst the royal captives who followed in the train were slowly moved along, with horrible yells, and shrilling screams, and frantic dances, and infamous contumelies, and all the unutterable abominations of the furies of hell in the abused shape of the vilest women.'

16. See for instance ibid., p. 34.

17. Billie MELMAN, The Culture of History, English Uses of the Past, 1800-1953, Oxford: OUP, 2006, xii, 363pp., pp. 29-31.

18. Walter SCOTT, The Life of Napoleon Buonaparte, Emperor of the French, with a Preliminary View of the French Revolution, Paris: Treuttel \& Würz, 1827, IX vol., I, 228.

19. Thomas CARLYLE, The French Revolution, a History (1837), ed. Ken J. FIELDING and David SORENSEN, Oxford: OUP, 1989, xlii, 501, 527 pp., II, 351.

20. Ibid., II, 328.

Revue Française de Civilisation Britannique, XV-4 | 2010 
21. These occurrences are too frequent to quote exhaustively: 'Rascality' appears 29 times, 'mob' 28, 'populace' 16 and 'canaille' 9. See for instance 'black deluges of rascality' accompanying the royal carriage (ibid., I, 299), or Général Ronsin's description of revolutionary troops as 'the elixir of the Rascality of the Earth' (II, 359).

22. Ibid., I, 35.

23. See for instance ibid., I 38-39, 101, 121.

24. I, 128. Many similar examples can be found. For instance, as the king passes by, a peasant in rags is about to bury his brother who has died of hunger (I, 21-22). Generally, scenes of insurrection or celebration often comprise many colourful characters of all trades (I, 199-201, $360)$.

25. Cf. Billie MELMAN, The Culture of History, op. cit., p. 49-53.

26. Those three semantic fields are present throughout the book, with, notably, the following polyptotons and variations: 'wildness': 'wild', 'wilderness', 'bewilderment', 'savage', 'savages', 'ferocious', cruel'. 'evil': ‘daemonic', ‘daemons', ‘pandemonium', ‘devils', ‘Satan'. ‘mad': ‘madman', 'maddened', 'frenzy', 'hysterics'.

27. The narrator can be heard marvelling at the creativity of French troops (reconnoitring Austrian positions in a balloon): 'What will not these devils incarnate contrive?' (The French Revolution, II, 374). Also, 'madness' comes sometimes close to just anger, with the narrator prompting: 'Forward, ye maddened sons of France' (I, 192-193).

28. See for instance I, 260.

29. II, 377 and I, 40.

30. I, 217.

31. See also the justification for the regicide (II, 204-205). Carlyle argues against 'retrospective Magnanimity', insisting on the constant dangers incurred by revolutionaries, and on the fear that a giant, even bound to the ground, may rise again (an image possibly reminiscent of Gulliver's Travels).

32. I, 443.

33. I, 121.

34. See for instance I, 111, 116; II, 125, 193, 364, 421.

35. I, 372; II, 239.

36. Jacques CABAU, Thomas Carlyle ou le Prométhée enchainé, Paris: Presses universitaires, 1968, 530 pp. - see, in particular, the section entitled 'baptême du feu', pp. 312-345. Although Cabau argues for the prevalence of fire, I would contend that water is at least as important.

37. I, 174-175, 292; II, 110-111, 107.

38. A possible exception is Mirabeau, who is to the multitude what the moon is to the tide (I, 131). 39. The French translation will be used here: Hans BLUMENBERG, Naufrage avec Spectateur (1979), translated by Laurent Cassagnau (Paris: l'Arche, 1994, 115 pp.). It is available in English as Shipwreck with Spectator (MIT Press, 1997).

40. See notably the last few pages of Carlyle's The French Revolution ('One other Sansculottic submersion, or at most two, and this wearied vessel of a Convention reaches land.' II, 436).

41. Ibid., I, 117, 121, 320, 342, 430; II, 165, 438.

42. Collected Letters, VI, 446, letter to John Stuart Mill dated September 1833. See also Carlyle's historiographic essays, 'On History' and 'On History Again'.

43. Hans BLUMENBERG, Naufrage avec spectateur, p. 14.

44. Ibid., p. 55.

45. Ibid. p. 34 .

46. Ibid., 56, 98.

47. Cf Carlyle's historiographic considerations, in 'On History again' especially.

48. Thomas CARLYLE, The French Revolution, I, 296, 323-324, II, 258, 127, 412. 
49. I, 351. The national Scottish Covenant was directed against the religious plans of Charles I. It can be seen as a contributing factor to the civil wars and, ultimately, the execution of the king, hence perhaps the added relevance of the comparison.

50. II, 261.

51. Ibid.

\section{ABSTRACTS}

Not only did the impact of the French Revolution in Britain come from the events themselves, but it also largely stemmed from the power of the written word. The country's identity, institutions and social fabric were potentially dependent on the 'literature of power' wielded by its political thinkers. Thomas Carlyle's The French Revolution (1837) came at a crucial juncture. He preceded the professional historians who aimed mostly for a 'literature of knowledge'. And yet, the chronological distance enabled him to propose an innovative and unique form of 'literature of power' on the Revolution. While keeping up with the violent imagery of earlier representations, he proceeded to re-humanise the mob, seeking justifications through rational arguments and original metaphors alike, emphasising the inevitability of what was akin to a natural disaster. As a result, the British reader could no longer think himself above a similar experience. Thanks to the reassuring blanket of time elapsed, the possibility of a British revolution on the French model could bear thinking about with less violent rejection, but also with a certain frisson and still a potential sense of foreboding. Carlyle took up the opportunity to hint at Britain's social problems of the 1830s, producing in the end a powerful text in social history.

Au-delà des événements, l'impact de la Révolution française en Grande-Bretagne se fit sentir à travers le pouvoir des textes écrits qui la représentaient. L'identité, les institutions et la cohésion sociale du pays pouvaient dépendre de la «littérature de pouvoir " maniée par ses penseurs politiques. The French Revolution (1837) de Thomas Carlyle arriva à un moment charnière. Carlyle appartenait à une tradition antérieure à celle des historiens professionnels aspirant à une "littérature de savoir»; mais le temps écoulé lui permettait de proposer une forme de " littérature de pouvoir » novatrice et unique sur la Révolution. S'il conserva l'imagerie violente des représentations précédentes, il rendit les débordements populaires plus humains, présentant des justifications tant rationnelles que métaphoriques, mettant l'accent sur l'inévitabilité de ce qui s'apparentait à un cataclysme naturel. De fait, le lecteur britannique ne pouvait plus se sentir au-dessus d'une telle expérience. Grâce au nombre rassurant d'années écoulées, la perspective d'une révolution britannique sur le modèle français pouvait être envisagée sans être aussi violemment rejetée, tout en suscitant un certain frisson. Carlyle saisit cette occasion pour inclure des allusions aux problèmes sociaux britanniques des années 1830, finissant par écrire un puissant texte d'histoire sociale.

\section{AUTHOR}

\section{CATHERINE HEYRENDT-SHERMAN}

Université de Reims 